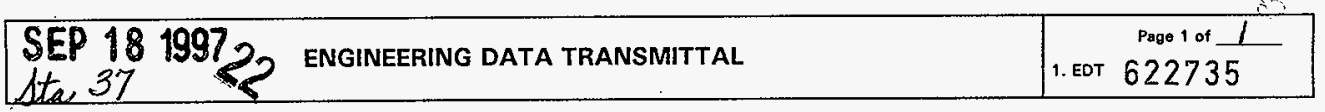

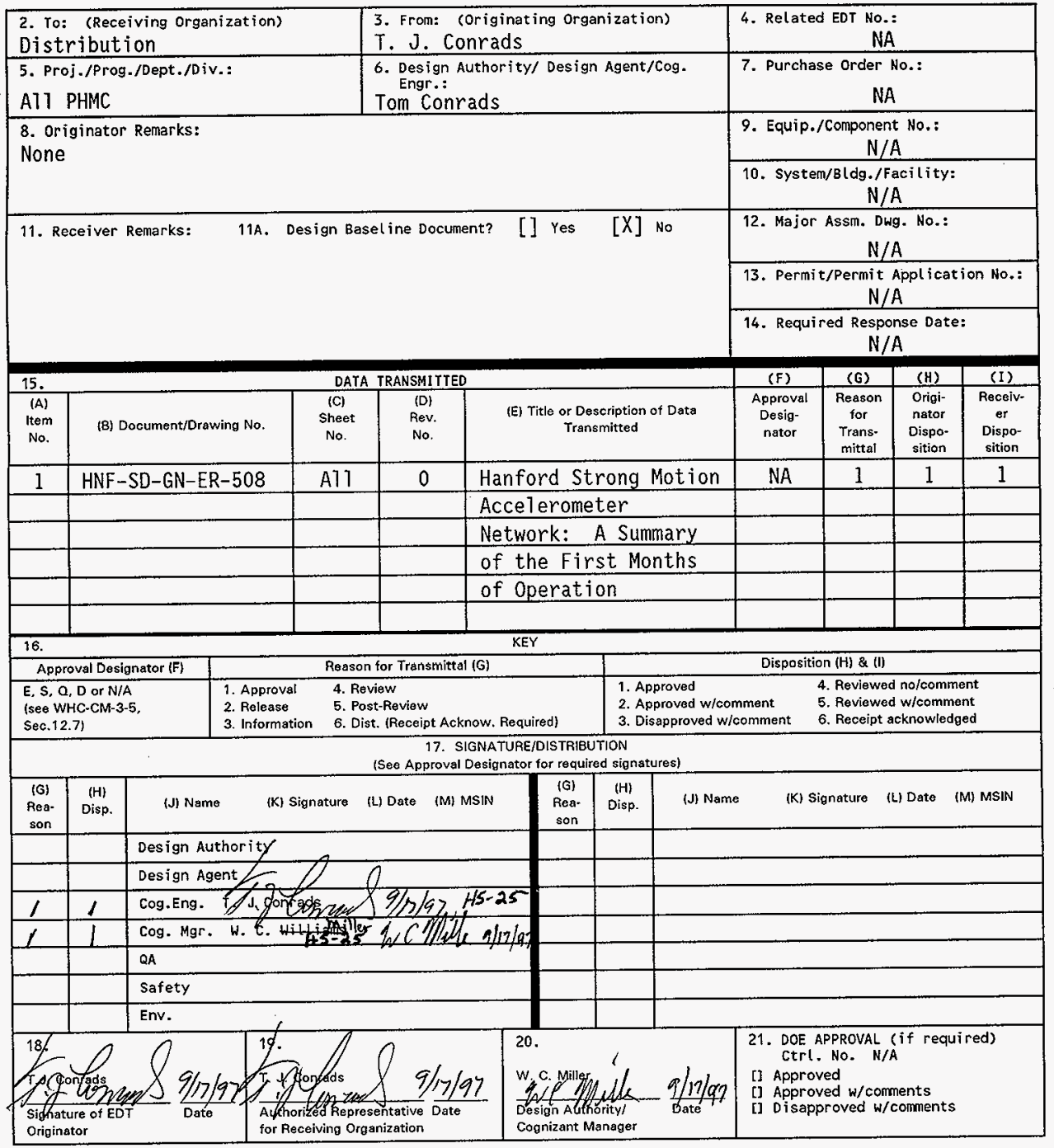

BD-7400-172-2(05/96) GEF097 


\section{Hanford Strong Motion Accelerometer Network: A Summary of the First Months of Operation}

T. J. Conrads

Numatec Hanford Company, Richland, WA 99352

U.S. Department of Energy Contract DE-AC06-96RL13200

EDT/ECN: 622735

UC: 607

Org Code: $8 C 400$

B\&R Code: YN010000

Charge Code: MDM77 $\mathrm{cP}_{1.91}$

Key Words: Seismic, instrumentation, emergency response

Abstract: This document describes the design, installation, and brief operation of a strong motion accelerometer system at the Hanford Site. This system was to be used by Site staff following a significant earthquake to assess possible structural damage by comparing the ground motion spectra to facilities' seismic design criteria

TRADEMARK DISCLAIMER. Reference herein to any specific commercial product, process, or service by trade name, tradenark, manufacturer, or otherwise, does not necessarily constitute or imply its endorsement, recommendation, or favoring by the United States Government or any agency thereof or its contractors or subcontractors.

Printed in the United States of America. To obtain copies of this document, contact: Document Control Services; P.0. Box 950, Mailstop H6-08, Richland HA 99352, Phone (50́9) 372-2420; Fax (509) 376-4989.
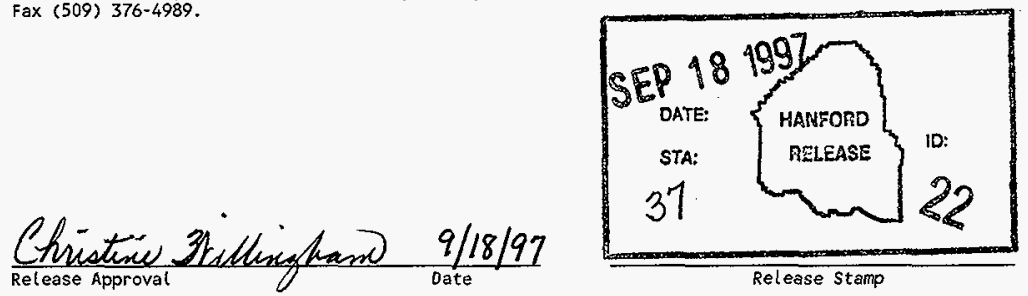

Release Stamp

\section{Approved for Public Release}



LEGAL DISCLAIMER

This report was prepared as an account of work sponsored by an agency of the United States Government. Neither the United States Government nor any agency thereof, nor any of their employees, nor any of their contractors, subcontractors or their employees, makes any warranty, express or implied, or assumes any legal liability or responsibility for the accuracy, completeness, or any third party's use or the results of such use of any information, apparatus, product, or process disclosed, or represents that its use would not infringe privately owned rights. Reference herein to any specific commercial product, process, or service by trade name, trademark, manufacturer, or otherwise, does not necessarily constitute or imply its endorsement, recommendation, or favoring by the United States Government or any agency thereof or its contractors or subcontractors. The views and opinions of authors expressed herein do not necessarily state or reflect those of the United States Government or any agency thereof.

This report has been reproduced from the best available copy.

Printed in the United States of America

DISCLM-2.CHP $\{1-91\}$ 


\begin{abstract}
This report describes the Fanford Strong Motion Accelerometer Network and the results of the operation of the network through FY97. Five Strong Motion Accelerometers have been installed in "Free-Field" locations at the 200 Areas, the $100 \mathrm{~K}$ Area, and the 300 and 400 Areas in compliance with DOE Order 5480-28, Natural Phenomena Hazards Mitigation. The data will be used by Emergency Operations Center staff and structural engineers to determine if the seismic design criteria for facilities was exceeded during an earthquake. Each of these areas was selected because of the large number of employees working at these locations and also because of hazardous material being stored at these locations. Appropriate operating levels and system maintenance checks to confirm the continuous operability of these instruments have been determined during the initial months of operation. The optimal operating levels and settings are based on an analysis of the external strong motion accelerometer triggers that occurred during FY97. These triggers and their sources are described in this report. As of October 1, 1997 the Hanford Strong Motion Accelerometer Network will be demobilized due to lack of priority for funding from the PHMC.
\end{abstract}




\section{CONTENTS}

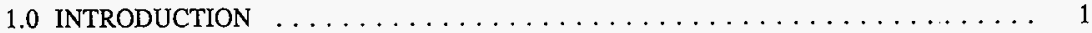

2.0 STRONG MOTION ACCELEROMETER STTES $\ldots \ldots \ldots \ldots \ldots \ldots \ldots \ldots \ldots$

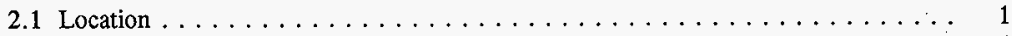

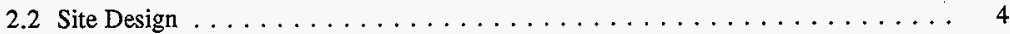

2.3 Strong Motion Accelerometer Operations Center .............. 4

3.0 RESULTS OF FIRST MONTHS OF OPERATIONS $\ldots \ldots \ldots \ldots \ldots \ldots \ldots$

3.1 Testing and Setting of Trigger Threshold Levels $\ldots \ldots \ldots \ldots \ldots \ldots \ldots$

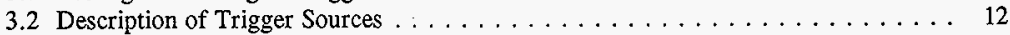

3.3 SMA GPS Location Performance $\ldots \ldots \ldots \ldots \ldots \ldots \ldots \ldots \ldots \ldots \ldots$

3.4 SMA GPS Clock Performance $\ldots \ldots \ldots \ldots \ldots \ldots \ldots \ldots \ldots \ldots \ldots$

4.0 CAPABILITIES IN THE EVENT OF A SIGNIFICANT EARTHQUAKE $\ldots \ldots \ldots \ldots 20$

4.1 Use of the SMA Network in the Event of an Earthquake . . . . . . . . 20

4.2 Earthquake Response Capability of the Seismic Monitoring Team $\ldots \ldots \ldots \ldots 20$

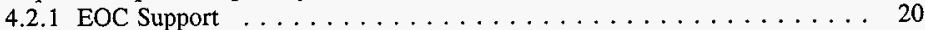

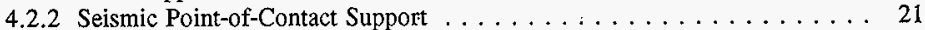

4.2.3 Earthquake Reporting by Seismic Monitoring Team . . . . . . . . 21

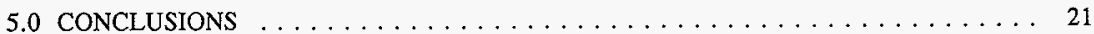

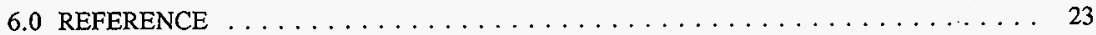

APPENDIX A AS-BUILT DRAWING FOR A STRONG MOTION ACCELEROMETER SITE

APPENDIX B LOCATIONS OF FREE FIELD STRONG MOTION ACCELEROMETER SITES 


\section{FIGURES}

1 Location of Hanford Strong Motion Accelerometer Sites . . . . . . . . . . . . 3

2 Typical Hanford Strong Motion Accelerometer Installation . . . . . . . . . . . . . 5

3 Schematic Diagram of a Strong Motion Accelerometer Installation . . . . . . . . . . . . 6

4 Triggers at $100 \mathrm{~K}$, Threshold $0.01 \%$ full scale $(0.02 \% \mathrm{~g}) \ldots \ldots \ldots \ldots \ldots \ldots \ldots$

5 Triggers at $200 \mathrm{E}$, Threshold $0.01 \%$ full scale $(0.02 \% \mathrm{~g}) \ldots \ldots \ldots \ldots \ldots \ldots \ldots$

6 Triggers at $200 \mathrm{~W}$, Threshold $0.01 \%$ full scale $(0.02 \% \mathrm{~g}) \ldots \ldots \ldots \ldots \ldots \ldots$

7 Triggers at $300 \mathrm{~A}$, Threshold $0.01 \%$ full scale $(0.02 \% \mathrm{~g}) \ldots \ldots \ldots \ldots \ldots$

8 Triggers at $400 \mathrm{~A}$, Threshold $0.01 \%$ full scale $(0.02 \% \mathrm{~g}) \ldots \ldots \ldots \ldots$

\section{TABLES}

1 Free-Field Strong Motion Accelerometer Site . . . . . . . . . . . . . . . 2

2 Instrument Parameters for the Kinemetrics ETNA System in the Hanford

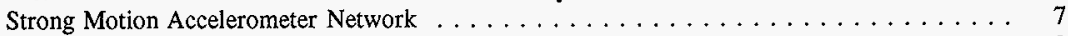

3 Present Trigger Levels Settings at Strong Motion Accelerometer Sites. . . . . . . . . . . 8

4 Trigger Times and Source Types Identified $\ldots \ldots \ldots \ldots \ldots \ldots \ldots \ldots$

5 Comparison of GPS Location and Locations Measured from Maps . . . . . . . . . . . . . . 19 
HNF-SD-GN-ER-508, REV. 0

\section{TERMS}

$\begin{array}{ll}\text { DOE } & \text { U.S. Department of Energy } \\ \text { EOC } & \text { Emergency Operations Center } \\ \text { GPS } & \text { Global Positioning System } \\ \text { PNNL } & \text { Pacific Northwest National Laboratory } \\ \text { POC } & \text { point of contact } \\ \text { RL } & \text { U.S. Department of Energy, Richland Operations Office } \\ \text { SMA } & \text { strong motion accelerometer } \\ \text { "g" } & \text { gravitational acceleration at earth's surface } \\ & \text { g = 32 feet/second } \\ \text { PHMC } & \text { Project Hanford Management Contract }\end{array}$




\subsection{INTRODUCTION}

The Hanford Seismic Monitoring network consists of two designs of equipment and sites: seismometer sites and strong motion accelerometer (SMA) sites. Seismometer sites are designed to locate earthquakes on and near the Hanford Site and determine their magnitude and hypocenter location. The U.S. Department of Energy (DOE) Order 5480.28, Natural Phenomena Hazards (DOE 1993) requires that facilities or sites that have structures or components in Performance Category 2 with hazardous material, and all Performance Category 3 and 4 facilities shall have instrumentation or other means to detect and record the occurrence and severity of seismic events. In order to comply with DOE Order 5480.28, the Hanford Seismic Monitoring Network seismometer sites needed to be complemented with strong motion accelerometers to record the ground motion at specific sites. The combined seismometer sites and strong motion accelerometer sites provide the Hanford Site with earthquake information to comply with DOE Order 5480.28. The data from these instruments will be used by the PHMC staff to assess the damage to facilities following a significant earthquake.

Because of PHMC funding priorities, this instrumentation system is being mothballed as of October 1, 1997.

\subsection{STRONG MOTION ACCELEROMETER SITES}

\subsection{Location}

The Hanford Strong Motion Accelerometer (SMA) network consists of five free-field SMA Sites (Figure 1) and one SMA housed in the 337 Building (Table 1 ). There is one free-field SMA located in each of the 200 Separations Areas, one adjacent to the K-Basins in $100 \mathrm{~K}$ Area, one adjacent to the 400 Area where the Fast Flux Test Reactor is located and one at the south end of the 300 Area. In addition one SMA is housed in the Office of Seismic Monitoring in the 337 building, 300 Area.

The instrumentation locations were chosen based on two criteria (Moore and Reidel 1996): 1) instruments should be located in areas having the highest densities of people; and 2) instruments should be located in areas having hazardous facilities. Some of the highest concentrations of employees at the Hanford Site are in the 200 East and West Areas, $100 \mathrm{~K}$ Area, the Fast Flux Test Facility (400 Area) and the 300 Areas. The 200 Areas are where all high level radioactive waste from past processing of fuel rods has been stored in single shell and double shell tanks. In addition the Canister Storage Facility that will hold encapsulated spent fuel rods is being constructed in the 200 East Area. The $100 \mathrm{~K}$ Area presently contains the $\mathrm{K}$ Basins where all spent fuel rods from the $\mathrm{N}$ Reactor are stored prior to encapsulation. The Cold Vacuum Drying Facility is presently being constructed in the $100 \mathrm{~K}$ Area to encapsulate spent fuel rods from the K Basins before shipment to the Canister Storage Building in 200 East Area. 
Table 1. Free-Field Strong Motion Accelerometer Sites.

\begin{tabular}{|c|c|c|c|c|}
\hline $\begin{array}{c}\text { Site } \\
\text { (Area) }\end{array}$ & $\begin{array}{l}\text { Site } \\
\text { ID }\end{array}$ & Location & $\begin{array}{l}\text { Latitude } \\
\text { Longitude } \\
\text { Elevation }\end{array}$ & Design \\
\hline $100 \mathrm{~K}$ & $\mathrm{H} 1 \mathrm{~K}$ & South of K Basins outside 100 Area fence. & $\begin{array}{l}46^{\circ} 38.51^{\prime} \\
119^{\circ} 35.53 \\
152 \mathrm{~m}\end{array}$ & $\begin{array}{l}\text { One free-field Kinemetrics ETNA Model } \\
\text { SMA housed in a ground vault. }\end{array}$ \\
\hline 200 East & $\mathrm{H} 2 \mathrm{E}$ & $\begin{array}{l}\text { East of B Plant; north of } 7 \text { th street and east } \\
\text { of Baltimore Ave. }\end{array}$ & $\begin{array}{l}46^{\circ} 33.58^{\prime} \\
119^{\circ} 32.00^{\prime} \\
210 \mathrm{~m}\end{array}$ & $\begin{array}{l}\text { One free-field Kinemetrics ETNA Model } \\
\text { SMA housed in ground vault. }\end{array}$ \\
\hline 200 West & $\mathrm{H} 2 \mathrm{~W}$ & $\begin{array}{l}\text { Northeast of Plutonium Finishing Plant } \\
\text { (PFP); north of } 19 \text { th street and east of } \\
\text { Camden Ave. }\end{array}$ & $\begin{array}{l}46^{\circ} 33.23^{\prime} \\
119^{\circ} 37.51^{\prime} \\
206 \mathrm{~m}\end{array}$ & $\begin{array}{l}\text { One free-field Kinemetrics ETNA Model } \\
\text { SMA housed in ground vault. }\end{array}$ \\
\hline 300 & $\mathrm{H} 3 \mathrm{~A}$ & $\begin{array}{l}\text { South end of } 300 \text { Area inside fence line. (NE } \\
1 / 4, \text { SW } 1 / 4, \text { Sec. } 11, \mathrm{~T} 10 \mathrm{~N}, \mathrm{R} 28 \mathrm{E} \text { ). }\end{array}$ & $\begin{array}{l}46^{\circ} 21.83^{\prime} \\
119^{\circ} 16.55^{\prime} \\
119 \mathrm{~m}\end{array}$ & $\begin{array}{l}\text { One free-field Kinemetrics ETNA Model } \\
\text { SMA housed in ground vault. }\end{array}$ \\
\hline 400 & $\mathrm{H} 4 \mathrm{~A}$ & $\begin{array}{l}500 \text { feet from fence line on east side of } \\
\text { facility and north of parking area). }\end{array}$ & $\begin{array}{l}46^{\circ} 26.13^{\prime} \\
119^{\circ} 21.30^{\prime} \\
171 \mathrm{~m}\end{array}$ & $\begin{array}{l}\text { One free-field Kinemetrics ETNA Model } \\
\text { SMA house in ground vault. }\end{array}$ \\
\hline $\begin{array}{l}337 \\
\text { Building }\end{array}$ & H3B & Office of Seismic Monitoring, Room 176 & $\begin{array}{l}46^{\circ} 22^{\prime} \\
119^{\circ} 17 \\
140 \mathrm{~m}\end{array}$ & $\begin{array}{l}\text { One Kinemetrics ETNA Model SMA } \\
\text { attached to concrete floor }\end{array}$ \\
\hline
\end{tabular}


HNF-SD-GN-ER-508, REV, 0

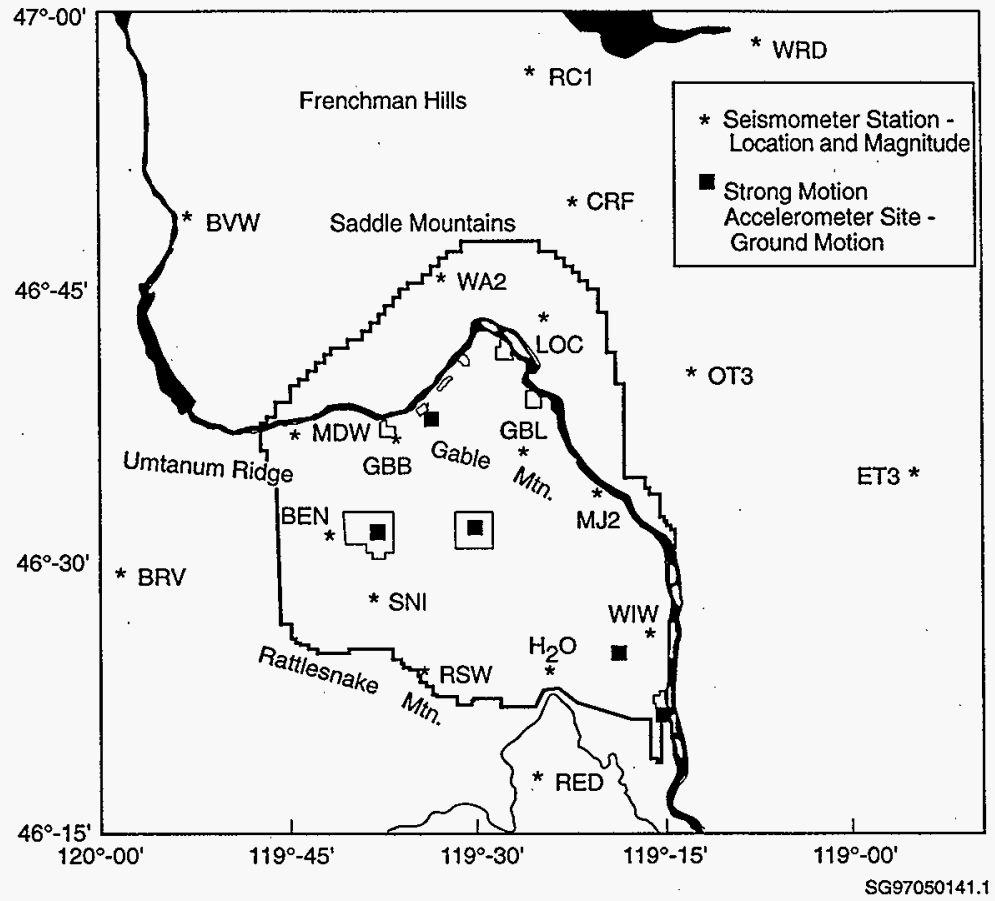

Figure 1. Location of Hanford Strong Motion Accelerometer Sites. 


\subsection{Site Design}

All free-field Strong Motion Accelerometer sites are constructed in a similar manner (Figure 2). The design consists of two 30-gallon drums set in the ground such that the base of the drum is about 1 meter below the surface. One drum houses only the SMA; the other drum houses the electronics and communications equipment. The drum containing the electronics and communications equipment is separated from the SMA drum by a distance of 40 to 85 inches and these drums are connected by a sealed conduit.

The SMA instruments are three-component units consisting of one vertical, one north-south horizontal, and one east-west horizontal data channel. The instruments in use at the time of this report are the ETNA system of Kinemetrics, Inc. Instrument specifications are summarized in Table 2. In addition to the three component Strong Motion Accelerometers, each ETNA SMA unit contains a computer, Global Positioning System receiver and a modem (Figure 3). These systems are housed in a water-tight box.

The SMAs are powered by two 100-amp-hour batteries that are housed in the equipment and communications drum (Figure 3). The batteries are charged by between two and four solar panels; a regulator is located between the solar panels and the batteries.

The communication link between the SMAs and the data analysis computer system housed in the 337 Building is via a cellular telephone/modem connection. The built-in modem in the SMA allows the system to use a cellular telephone to call an accelerometer or for the accelerometer to call out in the event it is triggered.

The SMAs have an internal Global Positioning System (GPS) receiver used principally to link it to the National Bureau of Standards timing system. The GPS is internally activated approximately every 4 hours and checks the location of the instrument and the time. Any differences between the internal clock and the GPS time are recorded and saved by the SMA. Any corrections to the internal timing are made automatically. After 6 months of operation the greatest difference recorded is approximately 4 milliseconds.

\subsection{Strong Motion Accelerometer Operations Center}

The combined operations, data recording and interpretation, and maintenance facility is located in the 337 Building and is operated by the PNNL Seismic Monitoring Team. This organization provides an area and point of contact for facility Emergency Response and Safety Personnel and facility managers to receive information in the event of an earthquake.

The present instrument parameters for the SMAs are given in Table 2. Each SMA unit consists of three Tri-axial Force Balance Accelerometers; one north-south, one east-west, and one vertical. 


\section{Free-field Strong Motion Accelerometer Site}

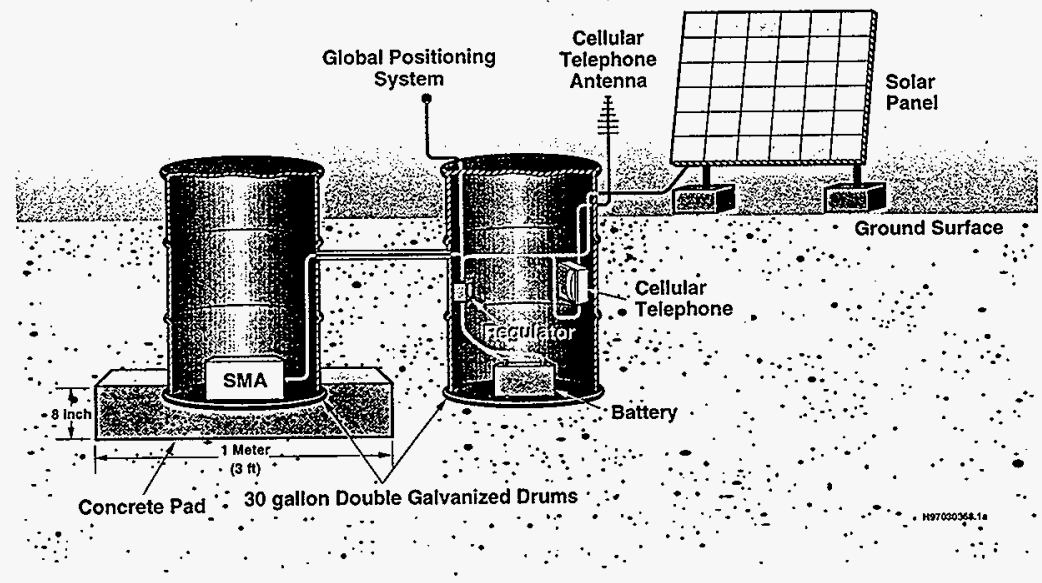

Figure 2. Typical Hanford Strong Motion Accelerometer Installation. 


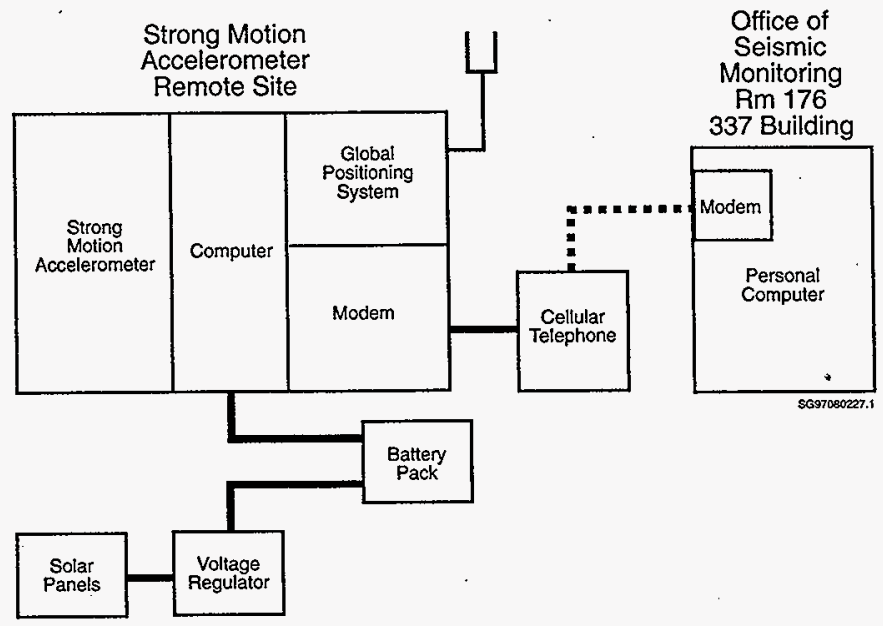

Figure 3. Schematic Diagram of a Strong Motion Accelerometer Installation. 
Each accelerometer channel is recorded and saved in memory; the signal consists of a preand post-event memory. When an accelerometer is triggered, 10 seconds of pre-event memory and 30 seconds of post-trigger memory are permanently recorded. The internal SMA computer records the analog signal in digital form. When one accelerometer channel is triggered, the other channels automatically record. The SMAs are currently set to trigger at thresholds from $0.04 \%$ to $0.20 \% \mathrm{~g}$.

The SMA network is designed to transmit the data to the Hanford Seismic Recording Center at the Office of Seismic Monitoring in the 337 Building or to be remotely accessed with a PC and modem. In addition, all SMAs can be accessed in the field where the data can be downloaded and interpreted.

Table 2. Instrument Parameters for the Kinemetrics ETNA System in the Hanford Strong Motion Accelerometer Network.

\begin{tabular}{|l|l|}
\hline \multicolumn{1}{|c|}{ Parameter } & \multicolumn{1}{|c|}{ Sensor } \\
\hline Type & $\begin{array}{l}\text { Tri-axial Force Balance Accelerometer, } \\
\text { orthogonally oriented with internal standard. }\end{array}$ \\
\hline Full-Scale & $2-2.5 \mathrm{~g}$ \\
\hline Natural Frequency & $50 \pm \mathrm{Hz}$ range \\
\hline Damping & approximately 70\% critical \\
\hline & Data Acquisition \\
\hline Number of Channels & 3 \\
\hline Sample Rate & 18 -bit resolution @ 200 samples/second \\
\hline Digital Output & Real-time, RS-232 Output Stream \\
\hline & Seismic Trigger \\
\hline Filter & $0.1-12.5 \mathrm{~Hz}$ \\
\hline Trigger level & $0.04 \% \mathrm{~g}$ to 0.20\% g * \\
\hline Alarm (call-out) Threshold & $4.00 \% \mathrm{~g}$ \\
\hline Pre-event Memory & $10 \mathrm{sec}$ \\
\hline Post-event Time & $30 \mathrm{sec}$ \\
\hline
\end{tabular}

* See Section 3 for discussion of trigger thresholds.

${ }^{1}$ Setting depends on instrument calibration. 


\subsection{RESULTS OF FIRST MONTHS OF OPERATIONS}

A test of the accelerometers was preformed to check their function and to determine practical trigger threshold levels for continued operation from July 16 to July 18,1997 . The objective is to determine the threshold which will result in recording local noise sources approximately once every few months at each system. This provides an additional check of the functioning of the complete system (in addition to routine checks by computer communication channels), and provides an opportunity to record ground motions from smaller earthquakes than could actually be considered to have damage potential to facilities (e.g. greater than $2.00 \%$ to $10 \% \mathrm{~g}$ ). Such events may be useful in calibrating ground motion relationships from larger events using empirical attenuation relationships.

\subsection{Testing and Setting of Trigger Threshold Levels}

The results of the test are shown in Table 3 below. All of the trigger thresholds were changed to the lowest possible value, based upon the signal levels observed during several triggers initiated by the computer (these do not relate to any particular level of ground motion). However, it was apparent that the noise environment over a longer time period is highly variable at some sites, due primarily to vehicular activities or loud low-frequency sound waves. For example, at $200 \mathrm{~W}$, the setting at $0.02 \% \mathrm{~g}$ (corresponding approximately to $0.01 \%$ full-scale) resulted in triggers approximately every 10 minutes, but at $100 \mathrm{~K}$ there were 3 triggers in 48 hours. Of the 20 triggers observed in 5 days at the 400 Area site, ten occurred between 7:03-7:15 a.m. and six occurred between 4:04 and 4:07 p.m. on workdays only. The remaining four triggers occurred between these two workday time periods; no triggers were observed over the weekend.

Since the end of the testing period through September 7, 1997, the trigger thresholds have been set as shown in Table 3 .

Table 3. Present Trigger Levels Settings at Strong Motion Accelerometer Sites.

\begin{tabular}{|l|l|l|}
\hline \multicolumn{1}{|c|}{ Site } & \multicolumn{1}{|c|}{ Trigger Level } & \multicolumn{1}{|c|}{$\begin{array}{c}\text { Trigger Level in Percent of } \\
\text { Full Scale }\end{array}$} \\
\hline $100 \mathrm{~K}$ & $0.0004 \mathrm{~g}(0.04 \% \mathrm{~g})$ & 0.02 \\
\hline $200 \mathrm{E}$ & $0.001 \mathrm{~g}(0.10 \% \mathrm{~g})$ & 0.05 \\
\hline $200 \mathrm{~W}$ & $0.002 \mathrm{~g}(0.20 \% \mathrm{~g})$ & 0.10 \\
\hline 300 & $0.001 \mathrm{~g}(0.10 \% \mathrm{~g})$ & 0.05 \\
\hline 400 & $0.001 \mathrm{~g}(0.10 \% \mathrm{~g})$ & 0.05 \\
\hline
\end{tabular}

The site at $100 \mathrm{~K}$ is clearly in the quietest and most remote location and can be left at a lower level than any other site. The site at $200 \mathrm{~W}$ was very noisy and thus was set at a higher level. After about 1.5 months, 2 of the 5 sites have triggered once. We are considering lowering the thresholds on the sites that have not triggered if the period exceeds 2 months without any triggers. 
Table 4. Trigger Times and Source Types Identified.

\begin{tabular}{|c|c|c|c|c|}
\hline Site & Trigger Date & Trigger Time & $\begin{array}{c}\text { Trìgger Threshold } \\
\text { (\% Full Scale) }\end{array}$ & Trigger Sources \\
\hline $100 \mathrm{~K}$ & $7 / 18 / 1997$ & $11: 06$ & 0.01 & acoustic, $<1$ second duration \\
\hline $100 \mathrm{~K}$ & $7 / 18 / 1997$ & $12: 23$ & 0.01 & acoustic, $<1$ second duration \\
\hline$-100 \mathrm{~K}$ & $7 / 18 / 1997$ & $12: 42$ & 0.01 & vehicle \\
\hline $100 \mathrm{~K}$ & $8 / 29 / 1997$ & $13: 24$ & 0.02 & acoustic, $<1$ second duration \\
\hline $200 \mathrm{E}$ & $7 / 17 / 1997$ & $20: 06$ & 0.01 & vehicle \\
\hline $200 \mathrm{~W}$ & $7 / 16 / 1997$ & $20: 51$ & 0.01 & vehicle \\
\hline $200 \mathrm{~W}$ & $7 / 16 / 1997$ & $20: 51$ & 0.01 & vehicle \\
\hline $200 \mathrm{~W}$ & $7 / 16 / 1997$ & $21: 02$ & 0.01 & vehicle \\
\hline $200 W$ & $7 / 16 / 1997$ & $21: 09$ & 0.01 & vehicle \\
\hline $200 \mathrm{~W}$ & $7 / 16 / 1997$ & $21: 17$ & 0.01 & vehicle \\
\hline $200 \mathrm{~W}$ & $7 / 16 / 1997$ & $21: 23$ & 0.01 & vehicle \\
\hline $200 \mathrm{~W}$ & $7 / 16 / 1997$ & $21: 32$ & 0.01 & vehicle \\
\hline 300 & $7 / 16 / 1997$ & $18: 47$ & 0.01 & acoustic, 3-second duration \\
\hline 300 & $7 / 16 / 1997$ & $19: 57$ & 0.01 & acoustic, 3-second duration \\
\hline 300 & $7 / 16 / 1997$ & $20: 27$ & 0.01 & vehicle \\
\hline 300 & $7 / 16 / 1997$ & $22: 04$ & 0.01 & acoustic, 3-second duration \\
\hline 300 & $7 / 17 / 1997$ & $20: 09$ & 0.01 & acoustic, 3-second duration \\
\hline 300 & $7 / 17 / 1997$ & $20: 29$ & 0.01 & acoustic, 3-second duration \\
\hline
\end{tabular}


Table 4. Trigger Times and Source Types Identified.

\begin{tabular}{|c|c|c|c|c|}
\hline Site & Trigger Date & Trigger Time & $\begin{array}{c}\text { Trigger Threshold } \\
\text { (\% Full Scale) }\end{array}$ & Trigger Sources \\
\hline 300 & $7 / 30 / 1997$ & $15: 14$ & 0.05 & acoustic, 3-second duration \\
\hline 400 & $7 / 16 / 1997$ & $23: 04$ & 0.01 & vehicle \\
\hline 400 & $7 / 16 / 1997$ & $23: 06$ & 0.01 & vehicle \\
\hline 400 & $7 / 17 / 1997$ & $14: 03$ & 0.01 & vehicle \\
\hline 400 & $7 / 17 / 1997$ & $14: 05$ & 0.01 & vehicle \\
\hline 400 & $7 / 17 / 1997$ & $14: 15$ & 0.01 & vehicle \\
\hline 400 & $7 / 17 / 1997$ & $14: 17$ & 0.01 & vehicle \\
\hline 400 & $7 / 17 / 1997$ & $18: 29$ & 0.01 & vehicle \\
\hline 400 & $7 / 17 / 1997$ & $18: 42$ & 0.01 & vehicle \\
\hline 400 & $7 / 17 / 1997$ & $23: 04$ & 0.01 & vehicle \\
\hline 400 & $7 / 17 / 1997$ & $23: 06$ & 0.01 & vehicle \\
\hline 400 & $7 / 18 / 1997$ & $14: 05$ & 0.01 & vehicle \\
\hline 400 & $7 / 18 / 1997$ & $14: 06$ & 0.01 & vehicle \\
\hline 400 & $7 / 18 / 1997$ & $14: 15$ & 0.01 & vehicle \\
\hline 400 & $7 / 18 / 1997$ & $23: 04$ & 0.01 & vehicle \\
\hline 400 & $7 / 18 / 1997$ & $23: 07$ & 0.01 & vehicle \\
\hline 400 & $7 / 21 / 1997$ & $14: 03$ & 0.01 & vehicle \\
\hline 400 & $7 / 21 / 1997$ & $14: 05$ & 0.01 & vehicle \\
\hline
\end{tabular}


Table 4. Trigger Times and Source Types Identified.

\begin{tabular}{|c|l|l|l|l|}
\hline Site & Trigger Date & Trigger Time & $\begin{array}{c}\text { Trigger Threshold } \\
(\% \text { Full Scale) }\end{array}$ & Trigger Sources \\
\hline 400 & $7 / 21 / 1997$ & $14: 16$ & 0.01 & vehicle \\
\hline 400 & $7 / 21 / 1997$ & $14: 45$ & 0.01 & vehicle \\
\hline
\end{tabular}




\subsection{Description of Trigger Sources}

Figures 4 through 8 show examples of the signals recorded during the trigger setting test. Figures $8 \mathrm{a}$ and $8 \mathrm{~b}$ show the many triggers recorded mainly at the beginning and end of the workday at $400 \mathrm{~A}$. These have the characteristics of vehicles in their envelopes, and their spectra show most of the energy in the frequency range $1-25 \mathrm{~Hz}$. Figure 6 shows the triggers at the 300 Area location, where impulsive, 3-second duration signals with power in their spectra from $20-80 \mathrm{~Hz}$ are typical of acoustic events. This is considered to be due to the close proximity to a set of shipping containers and the source is probably the slamming doors of containers.

Figures 5 and 6 show the data from the 200 West and 200 East sites. The signals are again typical of nearby vehicles. Only one trigger was obtained at 200 East before these sites' trigger thresholds were increased, and all three components of motion are shown for this site. The north-horizontal component is shown in all other plots.

Figure 4 shows the data from the $100 \mathrm{~K}$ site, which has the lowest noise of any of the five locations. At this site, there are a combination of high-frequency, short-duration ( $<1$ second) acoustic events and one vehicle. The last event is the only trigger to occur at this site in 6 weeks.

Note that in these plots, the apparent maximum signal often exceeds the stated trigger threshold level. The systems actually trigger on a filtered version of the recorded data, so only the signal with power between 0.1 and $12.5 \mathrm{~Hz}$ is used to trigger the system. This helps to avoid many of the acoustic noise sources and is expected to enhance the triggering behavior that is expected from actual earthquakes.

\subsection{SMA GPS Location Performance}

The locations of the five accelerometer sites were measured precisely from 7.5-minute quadrangle maps and compared to the locations determined from the output of the integral GPS element. In practically every case, the GPS measurements are in agreement to better than $100 \mathrm{~m}$. Elevations are expected to have greater errors for the GPS and so the values measured from the map will be used.

\subsection{SMA GPS Clock Performance}

The GPS time supplied to the systems has been monitored at least weekly throughout the summer and is typically consistent between locking modes (set at about every four hours) to within 1-2 milliseconds. This precision is adequate to maintain the digital time history precision of 5 milliseconds, which is the interval between samples (sampling at 200 samples/second). 


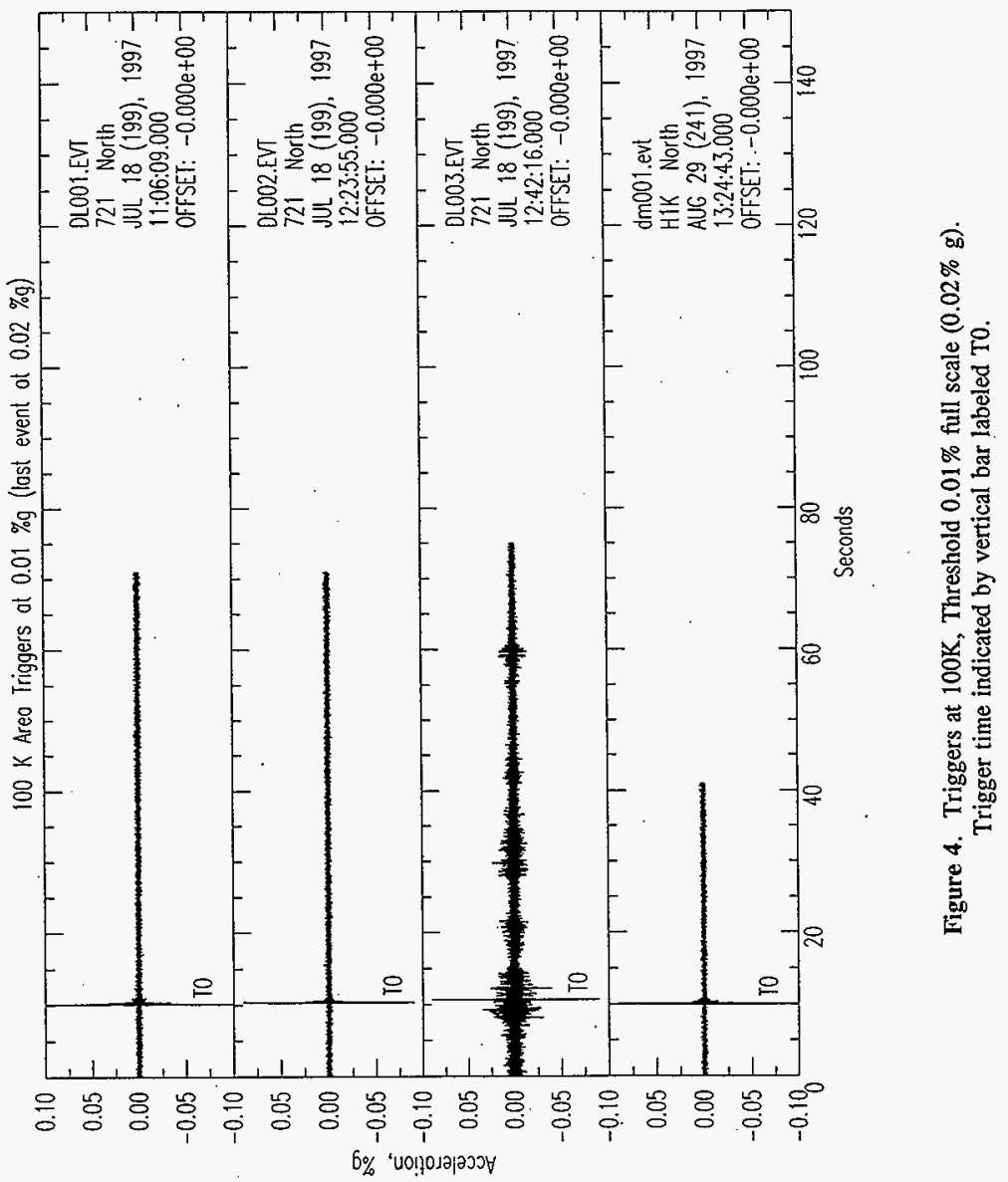




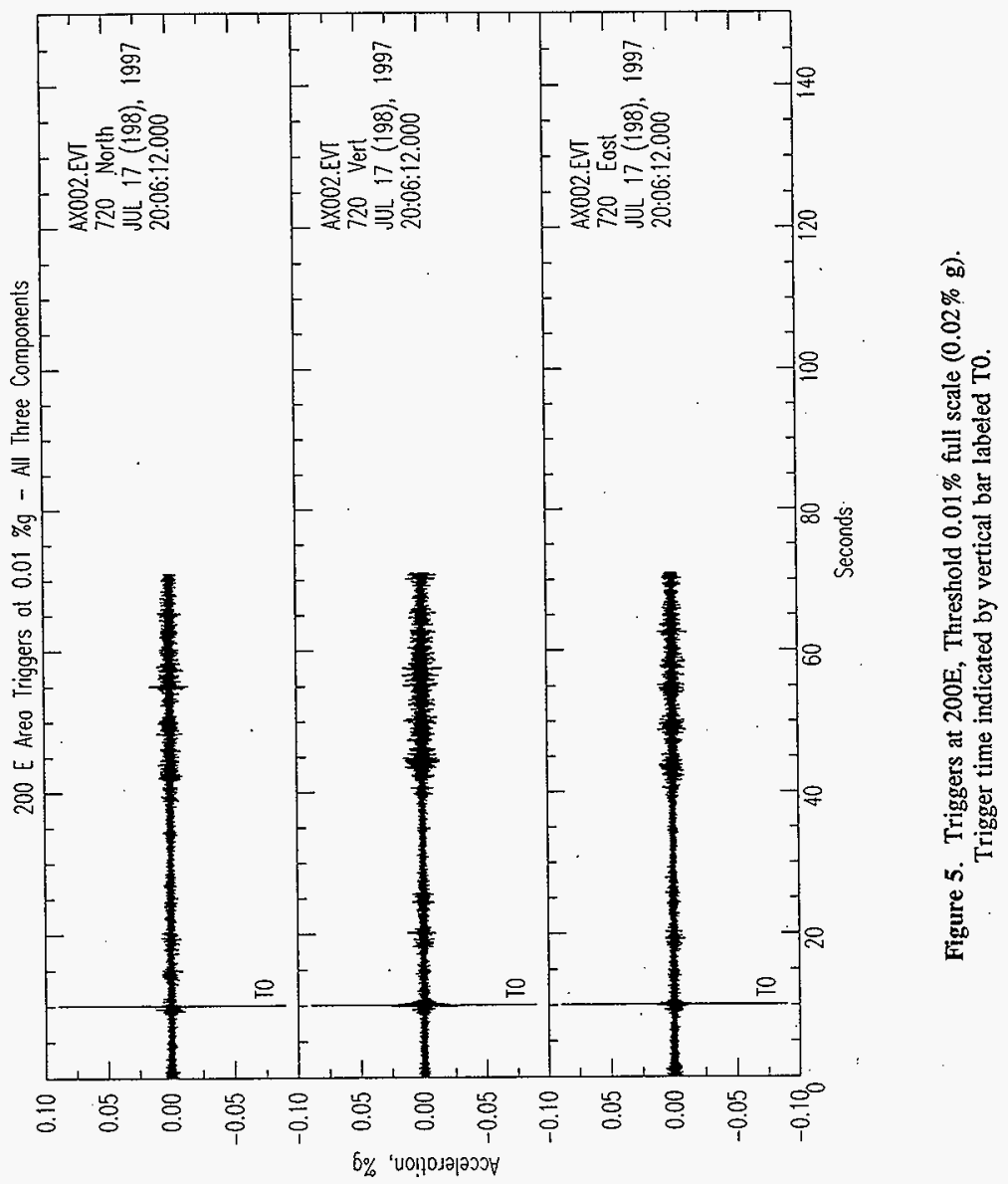


200 W Areo Triggers at $0.01 \% \mathrm{~g}$

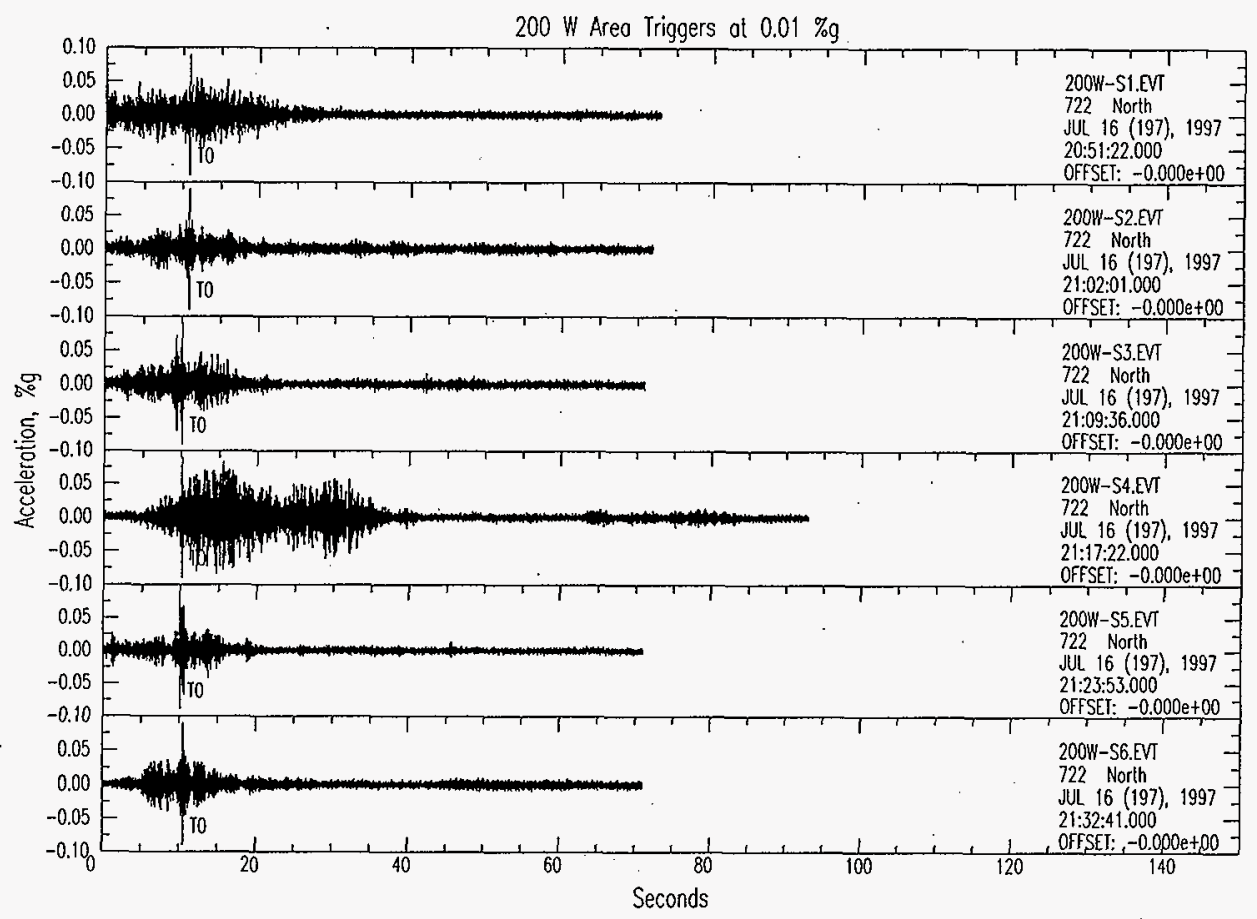

Figure 6. Triggers at $200 \mathrm{~W}$, Threshold $0.01 \%$ full scale $(0.02 \% \mathrm{~g})$.

Trigger time indicated by vertical bar labeled $\mathrm{TO}$. 
300 Areo Triggers at $0.01 \% 9$ (last event at $0.05 \% 9$ )

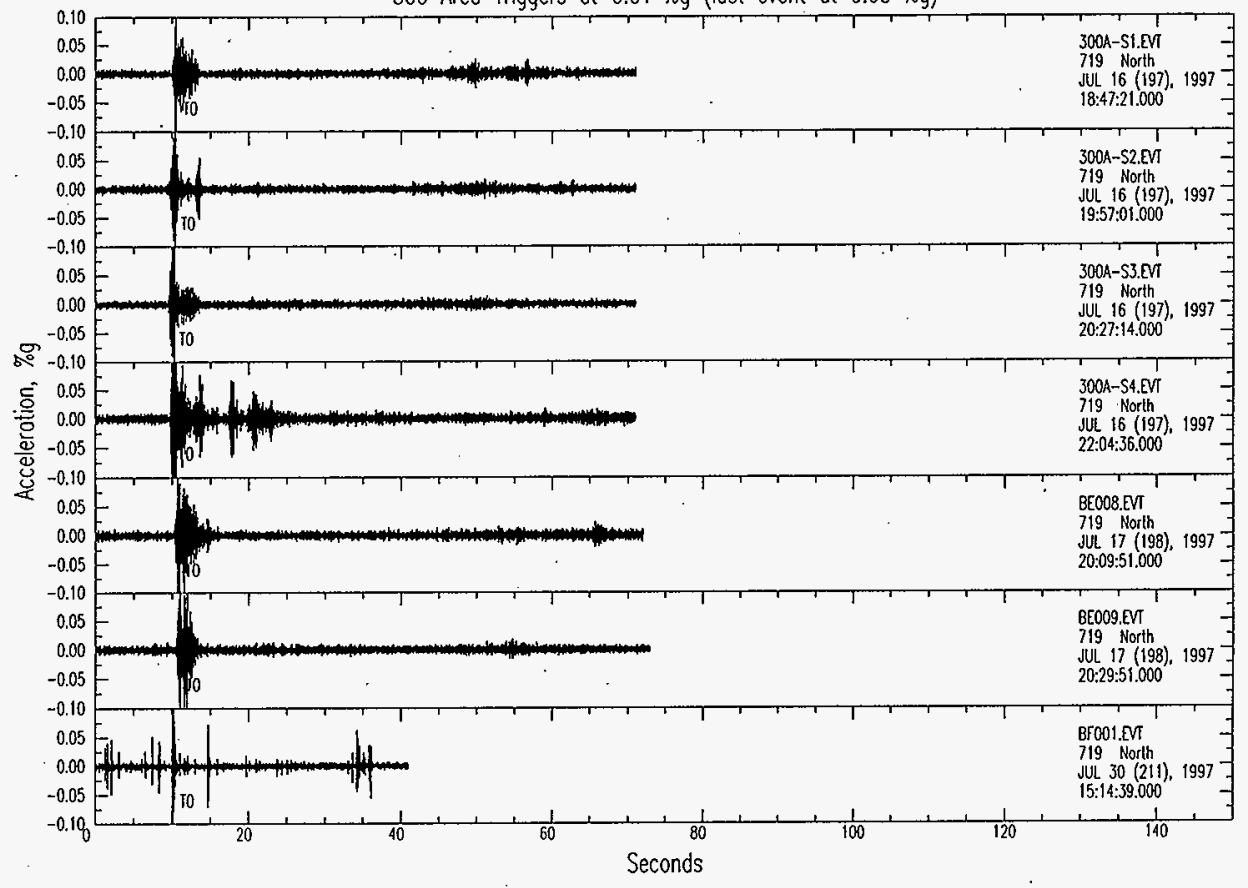

Figure 7. Triggers at $300 \mathrm{~A}$, Threshold $0.01 \%$ full scale $(0.02 \% \mathrm{~g})$. Trigger time indicated by vertical bar labeled $\mathrm{T} 0$. 


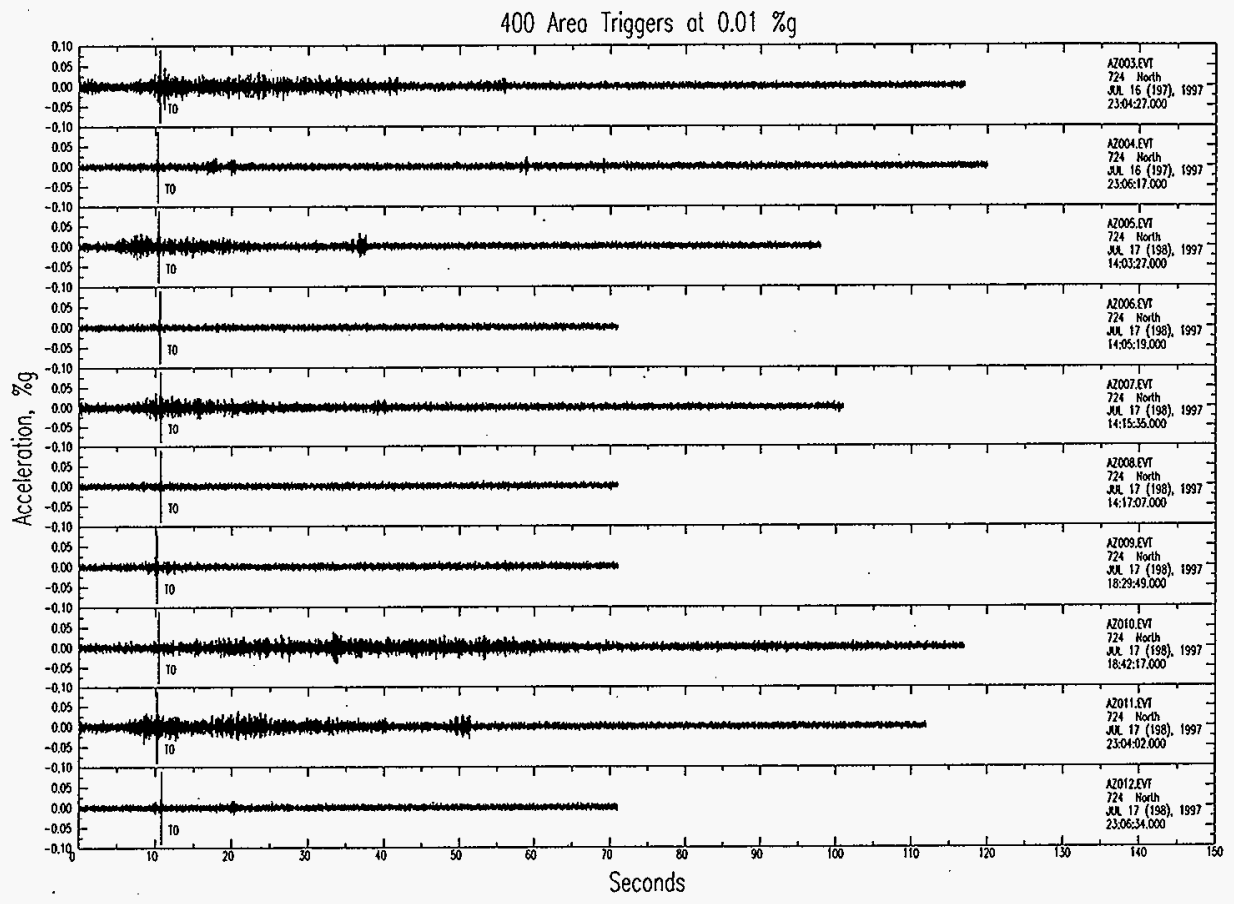

Figure 8. Triggers at $400 \mathrm{~A}$, Threshold $0.01 \%$ full scale $(0.02 \% \mathrm{~g}$ ). (sheet 1 )

Trigger time indicated by vertical bar labeled $\mathrm{T} 0$. 
400 Areo Triggers at $0.01 \% \mathrm{~g}$

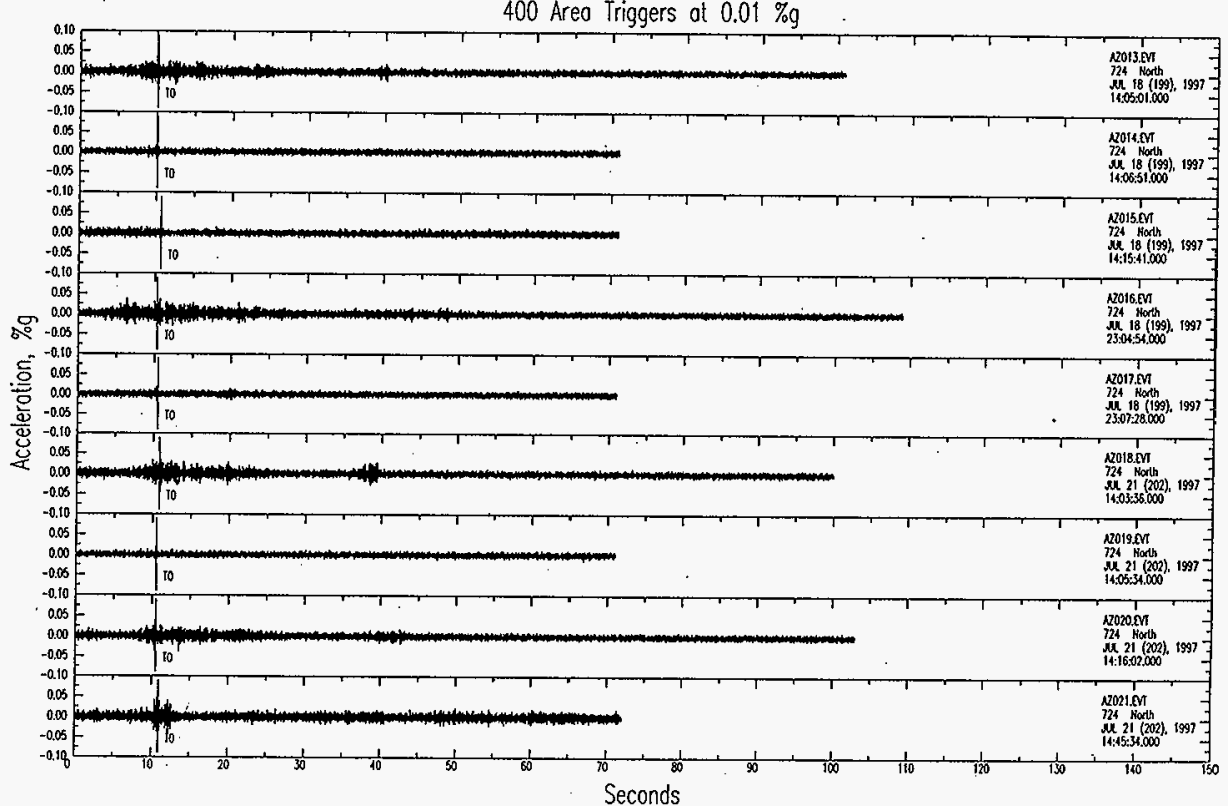

Figure 8. Triggers at $400 \mathrm{~A}$, Threshold $0.01 \%$ full scale $(0.02 \% \mathrm{~g})$. (sheet 2$)$ Trigger time indicated by vertical bar labeled $\mathrm{T} 0$. 
HNF-SD-GN-ER-508, REV. 0

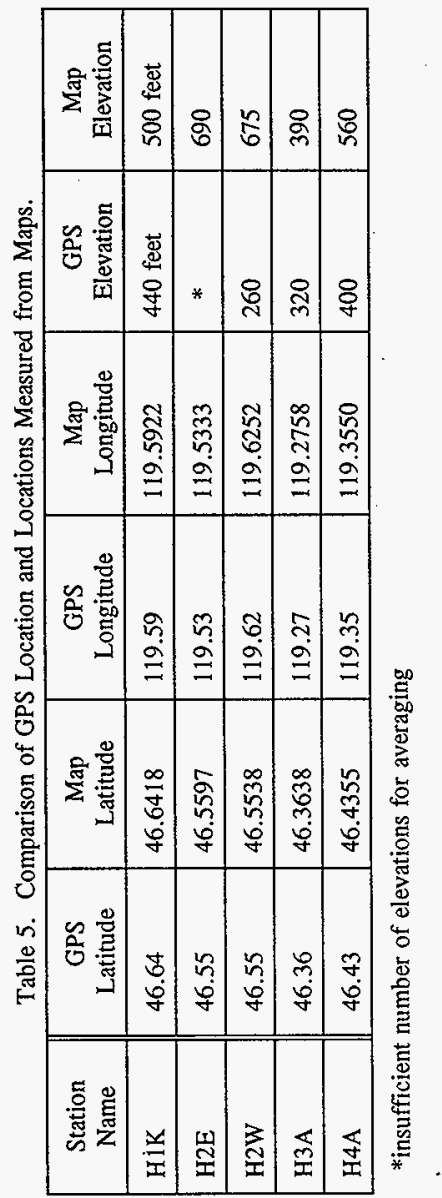




\subsection{CAPABILITIES IN THE EVENT OF A SIGNIFICANT EARTHQUAKE}

The strong motion accelerometer network was installed to comply with requirements contained in US DOE Order 5480.28, Natural Phenomena Hazards Mitigation. The SMA network was designed to provide ground motion in areas at Hanford that have high densities of people and/or have hazardous facilities. This section summarizes the capabilities of the Seismic Monitoring Team using the Hanford Strong Motion Accelerometer Network in the event of an earthquake at Hanford.

\subsection{Use of the SMA Network in the Event of an Earthquake}

Historically only a few Hanford sites have instruments that can provide data on peak ground accelerations or any type of ground motion at Hanford. The SMA instruments were located so that if an earthquake occurs, ground motion data will be readily available for assessing the damage of the $100 \mathrm{~K}$ Area, the 200 East and West Areas, the 300 and 400 Area facilities which have the greatest concentration of people and all the hazardous materials.

Facilities at Hanford have undergone various degrees of seismic analysis either during design or during requalification. Although the seismic design of a building may be known, when an earthquake is felt, a determination must be made as to the extent of damage before it can be reoccupied and the systems restarted. A felt earthquake may not cause any damage to a building, but without adequate characterization of the ground motion, initial determination of damage may be impossible.

The SMA network provides a very cost-effective vehicle to assess damage resulting from an earthquake. In the event of an earthquake building managers, emergency directors, and engineers can obtain ground motion data recorded by the SMA network from the Office of Seismic Monitoring. If a SMA is triggered, the Office of Seismic Monitoring will download events that were recorded and determine the peak ground accelerations and the spectral response curves. This information can then be used by the facility engineers to determine if the ground motion exceeded, was equal to, or was less than that used to design the building. This information, together with assessments from trained engineers, allows the facility manager to make a rapid and cost effective determination of whether a building is safe to reoccupy or should not be used until it has be inspected in more detail. Buildings that have seismic design criteria exceeding the recorded ground motion could be put back into service very quickly; buildings that are very close to or less than the measured ground motion could be given priority for onsite damage inspections.

\subsection{Earthquake Response Capability of the Seismic Monitoring Team}

\subsubsection{EOC Support}

The Seismic Monitoring team is trained to support the U.S. Department of Energy, Richland Operations Office (RL) Emergency Operations Center in the event of a significant earthquake and the EOC procedures have been updated to utilize this resource. If an earthquake occurs and the EOC is activated, a member of the Seismic Monitoring team will report to the EOC in the Federal Building if 
requested. A computer in the EOC is equipped so that the Seismic Monitoring team member can assess the strong motion accelerometer network and provide real-time support to the EOC.

\subsubsection{Seismic Point-of-Contact Support}

A member of the Seismic Monitoring team is on call 24 hours per day, seven days per week, all year long as a Point of Contact (POC) in case of emergencies involving earthquakes or to answer questions if the need arises. The name of the team member who is the POC is listed with the Hanford Patrol. Changes in the Seismic Monitoring POC due to any reason are reported to the Hanford Patrol so that someone is always available.

\subsubsection{Earthquake Reporting by Seismic Monitoring Team}

A capability currently being developed by the Seismic Monitoring team is to make use of the AUTOCALL mode of the strong motion accelerometer equipment. AUTOCALL is a feature in the SMA software that allows the SMA to call out to a predetermined telephone number if an instrument is triggered. The Seismic Monitoring team is developing this feature so that, in addition to calling the base computer station if an instrument is triggered, the computer will automatically call a pager number. This pager number will activate pagers carried by the Seismic Monitoring team any time of the day or night. This capability will allow the Seismic Monitoring team to monitor seismic activity 24 hours a day.

When the pager AUTOCALL system is operational the Seismic Monitoring team will use it to provide notification to the Hanford Patrol and Emergency Services in the event an earthquake triggers a SMA.

\subsection{CONCLUSIONS}

Five Strong Motion Accelerometers installed at the Hanford Site in "Free-Field" locations at 200 East and West Areas, the 100K Area, and the 300 and 400 Areas in compliance with DOE Order 5480.28 requirements to assist staff in the determination of damage following an earthquake. These sites were chosen because of the large number of employees quartered at these locations and because they include facilities storing hazardous material.

The instrumentation is installed in doubly galvanized drums that were set 1 meter in the ground. The SMA drum was set in a concrete pad and separated from the batteries and supporting instrument package. This installation was chosen because it provided the best protection from the elements and the best contact with the ground.

A series of tests was performed on the accelerometers during the summer of FY97 to ensure the installation and instruments operated properly. We have determined appropriate operating levels and system maintenance checks to confirm the continuous operability of these instruments. The present operating levels and settings are based upon an analysis of the external strong motion accelerometer triggers that occurred during FY97. The instruments are currently set to trigger at low 
threshold levels but high enough to avoid being repeatedly triggered by normal operations of the Hanford Site.

Emergency Operations Center procedures were upgraded and engineers trained to use the data to evaluate the structural adequacy of facilities following an earthquake. This data, together with structural assessments by trained engineers will allow Hanford staff to manage the aftermath of earthquakes and restart facilities in an orderly fashion.

The principal source of external triggers during the FY97 period of operations were anthropogenic sources near the sites. There were no earthquakes large enough during the short period of operation in FY97 to trigger any sites.

Until October 1, 1997, the Hanford Strong Motion Accelerometer Network will be fully operational. On October 1,1997 , the network will be demobilized and the trained facility inspection teams will no longer be maintained because of lack of priority for PHMC funding. 


\section{HNF-SD-GN-ER-508, REV. 0}

\subsection{REFERENCES}

DOE, 1993, Natural Phenomena Hazards, DOE Order 5480.28, U.S. Department of Energy, Washington, D.C.

Moore, Carlton, and Reidel, Stephen, 1996, Hanford Site Seismic Monitoring Instrumentation Plan, WHC-SD-GN-ER-30036, Westinghouse Hanford Company, Richland, Washington. 
HNF-SD-GN-ER-508, REV. 0

This page intentionally left blank. 
HNF-SD-GN-ER-508, REV. 0

\section{APPENDIX A}

\section{AS-BUILT DIAGRAM FOR A HANFORD STRONG MOTION ACCELEROMETER SITE}


HNF-SD-GN-ER-508, REV. 0

This page intentionally left blank 


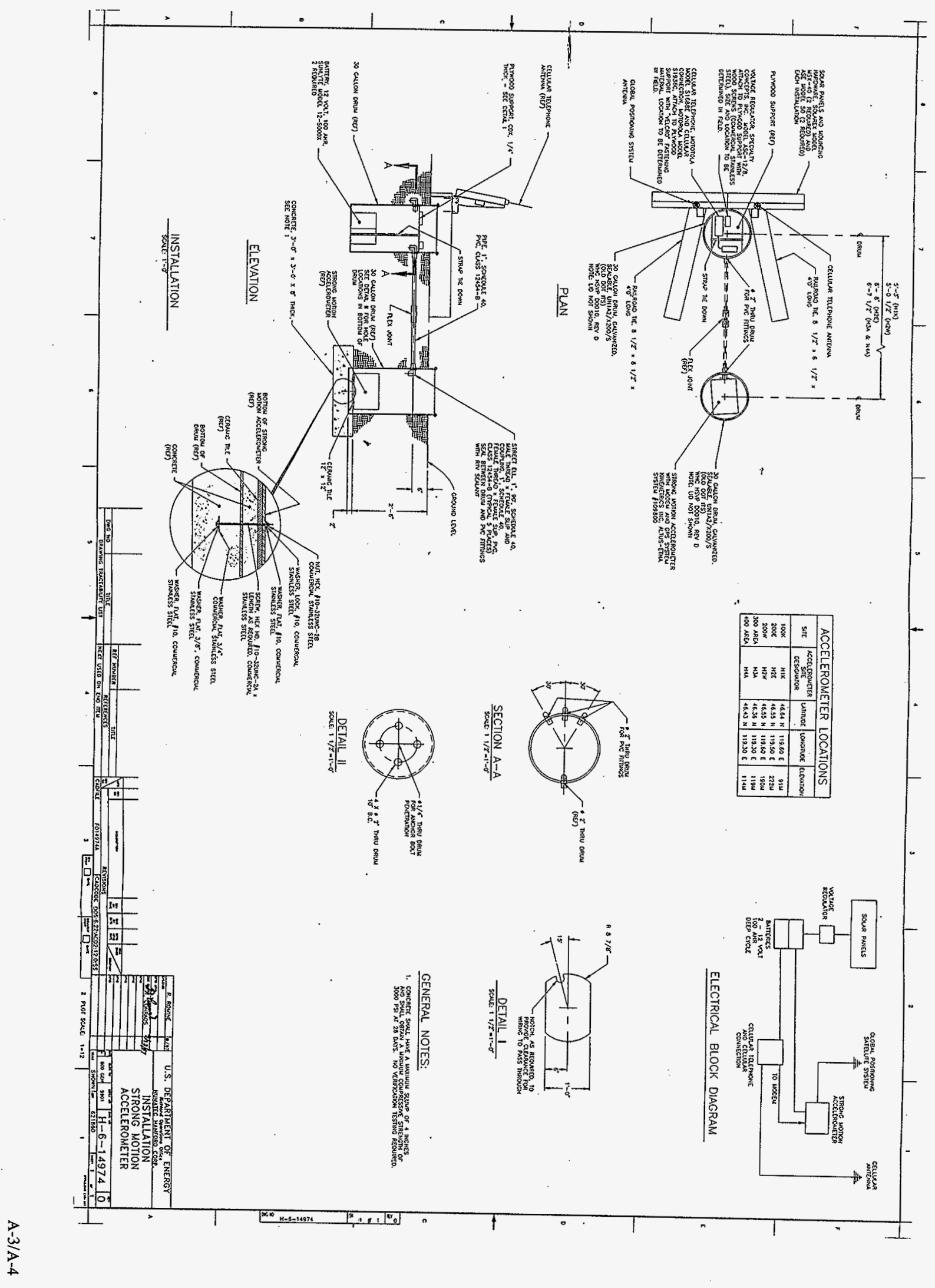

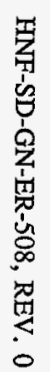


HNF-SD-GN-ER-508, REV. 0

\section{APPENDIX B}

\section{DETAILED LOCATIONS OF FREE-FIELD STRONG MOTION ACCELEROMETER SITES}


HNF-SD-GN-ER-508, REV. 0

This page intentionally left blank. 
HNF-SD-GN-ER-508, REV. 0

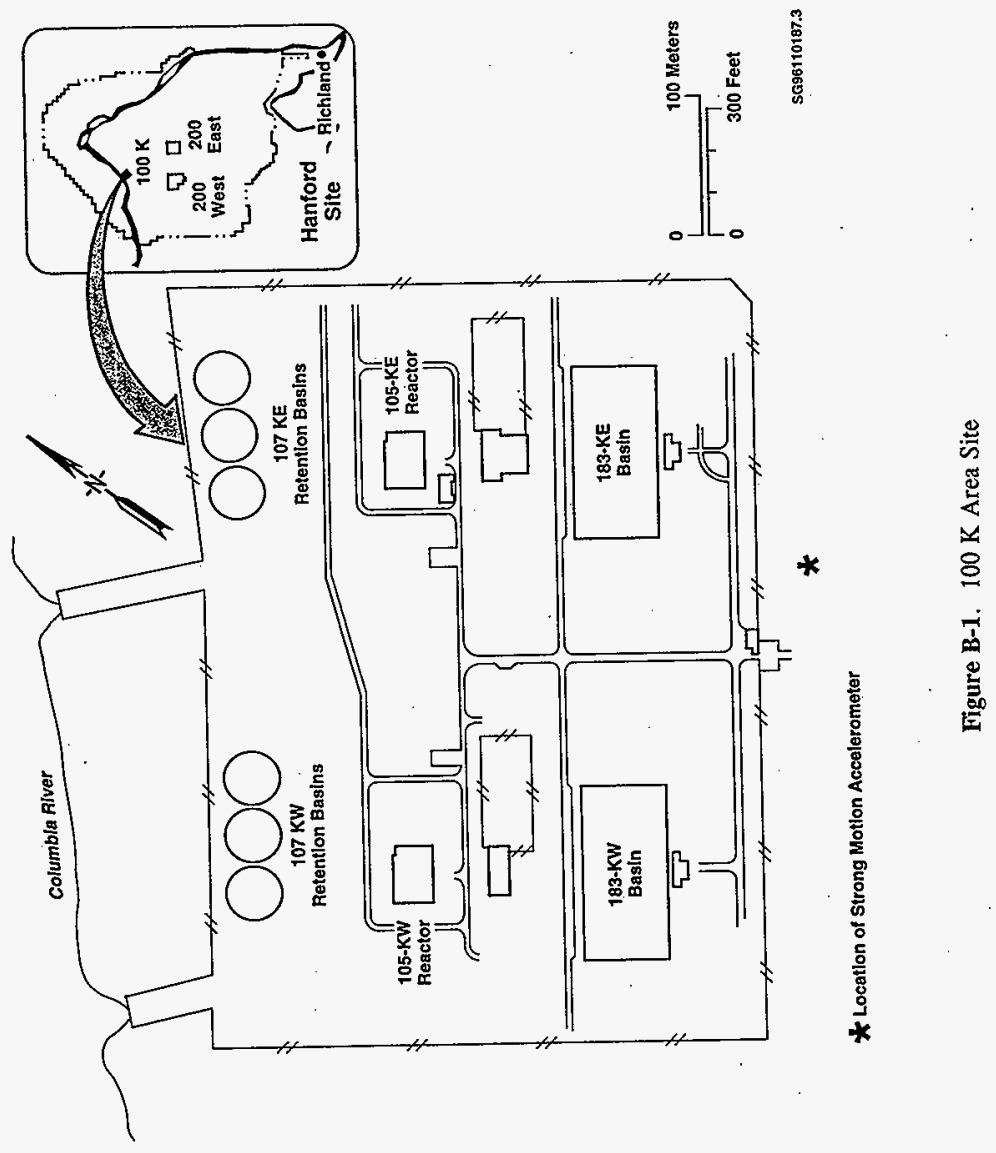


HNF-SD-GN-ER-508, REV. 0

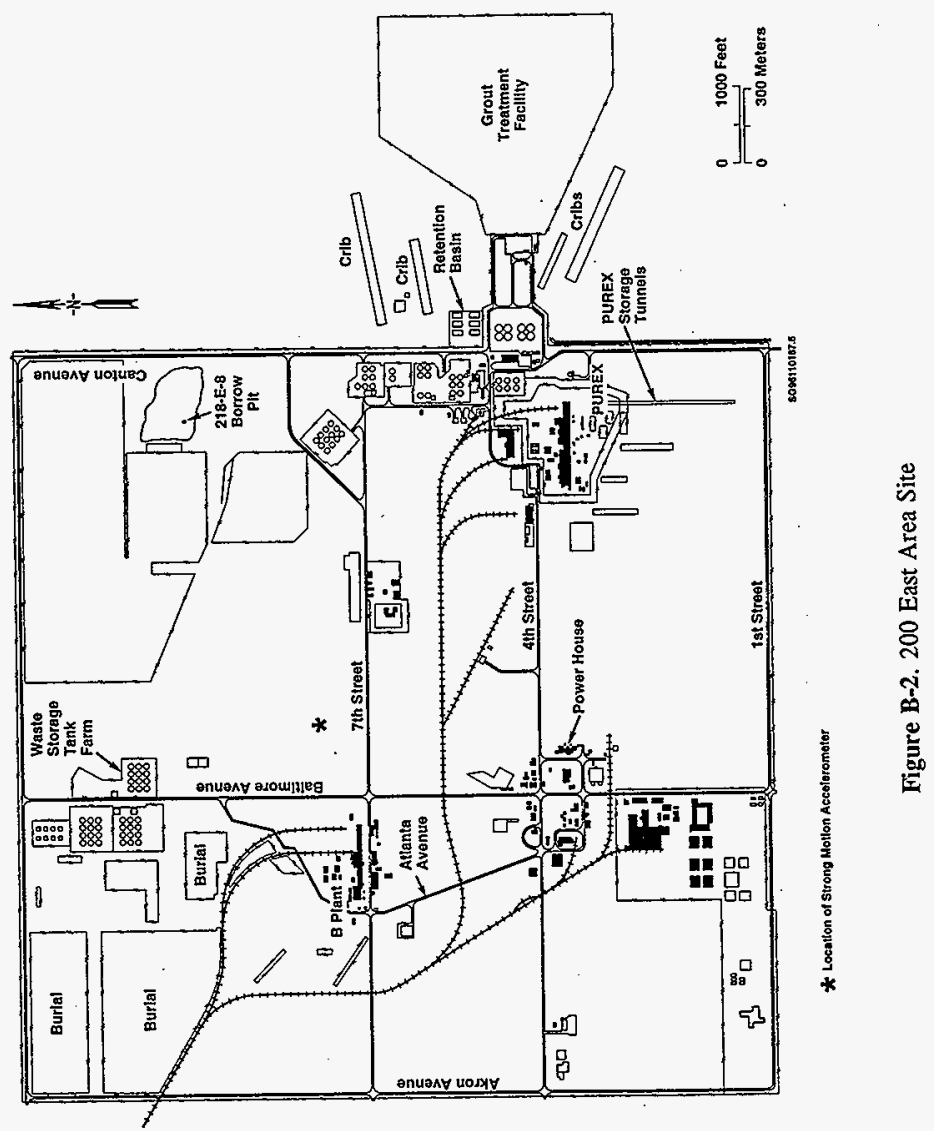




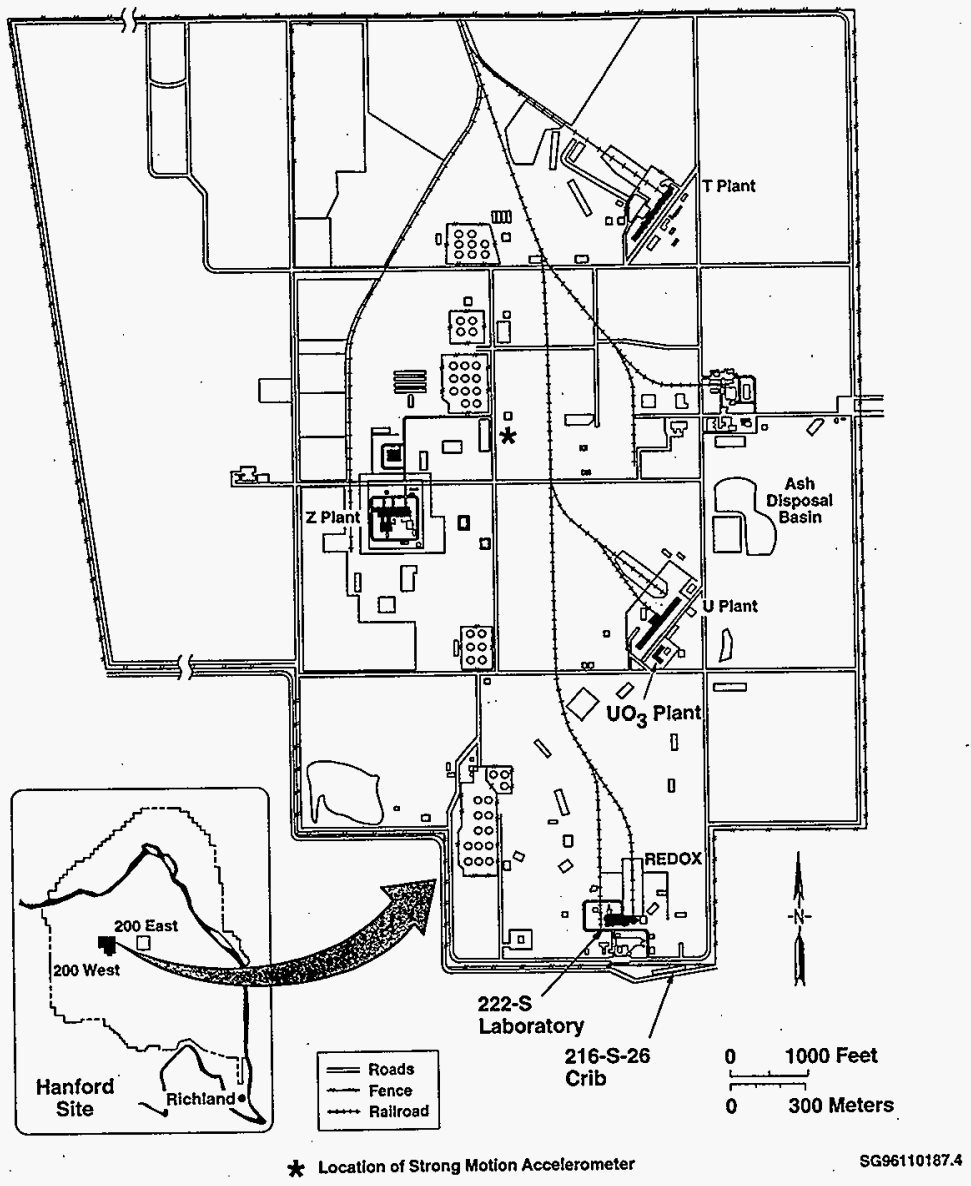

Figure B-3. 200 West Area Site 


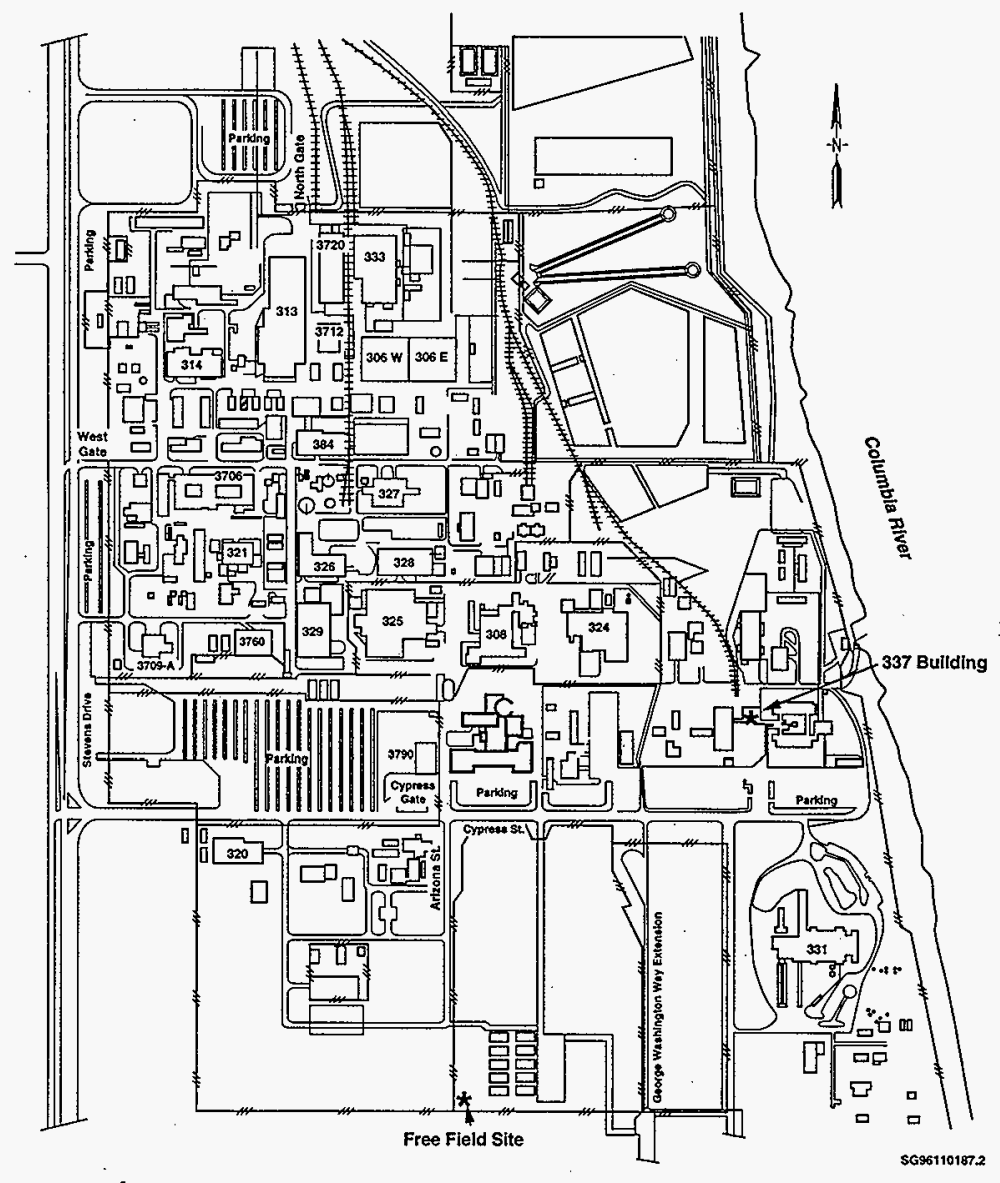

$\star$ Location of Strong Motion Accelerometer

Figure B-4. 300 Area Site. 
HNF-SD-GN-ER-508, REV. 0

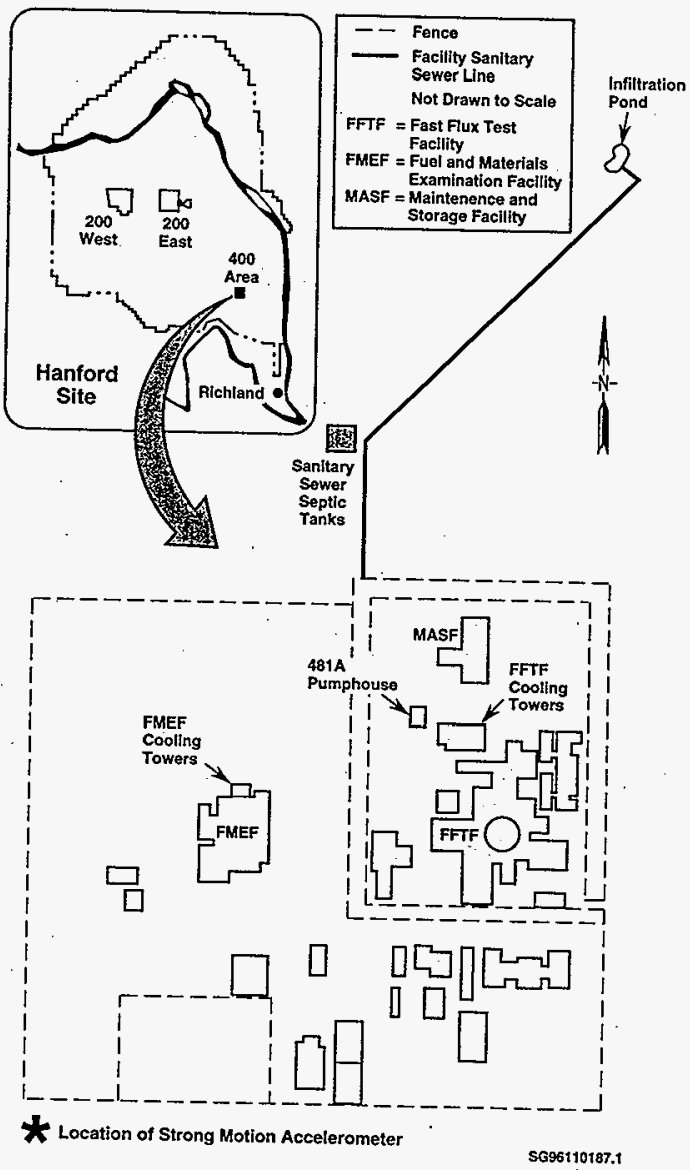

Figure B-5. 400 Area Site. 
HNF-SD-GN-ER-508, REV. 0

This page intentionally left blank

B-8 


\section{DISTRIBUTION SHEET}

\begin{tabular}{|c|c|c|c|c|c|}
\hline \multirow{2}{*}{$\begin{array}{l}\text { To } \\
\text { Distribution }\end{array}$} & \multirow{2}{*}{\multicolumn{3}{|c|}{$\begin{array}{l}\text { From } \\
\text { T. J. Conrads }\end{array}$}} & \multicolumn{2}{|l|}{ Page 1 of 1} \\
\hline & & & & \multicolumn{2}{|c|}{ Date $9 / 18 / 97$} \\
\hline \multirow{2}{*}{\multicolumn{4}{|c|}{ Project Title/Work Order }} & \multirow{2}{*}{\multicolumn{2}{|c|}{$\begin{array}{ll}\text { EDT No. } & 622735 \\
\text { ECN No. } & \text { N/A }\end{array}$}} \\
\hline & & & & & \\
\hline Name & MSIN & $\begin{array}{c}\text { Text } \\
\text { With All } \\
\text { Attach. }\end{array}$ & Text Only & $\begin{array}{c}\text { Attach./ } \\
\text { Appendix } \\
\text { Only }\end{array}$ & $\begin{array}{l}\text { EDT/ECN } \\
\text { Only }\end{array}$ \\
\hline $\begin{array}{l}\text { M. V. Berriochoa } \\
\text { H. D. Chauve } \\
\text { D. A. Conners } \\
\text { T. J. Conrads } \\
\text { J. T. Curtis } \\
\text { K. R. Fecht } \\
\text { M. J. Furman } \\
\text { D. C. Hartshorn } \\
\text { R. D. Hildebrand } \\
\text { G. R. Holdren } \\
\text { P. J. Mackey } \\
\text { F. C. Mann } \\
\text { J. Mcnealy } \\
\text { J. E. Mecca } \\
\text { W. C. Miller } \\
\text { T. P. Morales } \\
\text { M. R. Moreno } \\
\text { S. P. Reidel (15) } \\
\text { A. C. Rohay } \\
\text { E. R. Siciliano } \\
\text { R. M. Smith } \\
\text { K. M. Thompson } \\
\text { R. R. Thompson } \\
\text { J. L. Tokarz-Hames } \\
\text { M. I. Wood } \\
\text { M. T. York } \\
\text { Centrat Files (original }+1 \text { copy) }\end{array}$ & $\begin{array}{l}\mathrm{B} 3-30 \\
\mathrm{H} 5-25 \\
\mathrm{~T} 5-11 \\
\mathrm{~B} 1-17 \\
\mathrm{~B} 3-06 \\
\mathrm{H} 0-02 \\
\mathrm{H} 0-12 \\
\mathrm{~K} 6-81 \\
\mathrm{H} 0-12 \\
\mathrm{~K} 6-81 \\
\mathrm{~B} 3-15 \\
\mathrm{H} 0-31 \\
\mathrm{~A} 3-05 \\
\mathrm{R} 3-79 \\
\mathrm{H} 5-25 \\
\mathrm{~A} 3-05 \\
\mathrm{~A} 5-55 \\
\mathrm{~K} 6-81 \\
\mathrm{~K} 6-81 \\
\mathrm{H} 0-31 \\
\mathrm{~K} 6-96 \\
\mathrm{H} 0-12 \\
\mathrm{R} 2-12 \\
\mathrm{~A} 5-55 \\
\mathrm{~T} 3-01 \\
\mathrm{~T} 3-01 \\
\mathrm{~B} 1-03\end{array}$ & $\begin{array}{l}X \\
X \\
X \\
X \\
X \\
X \\
X \\
X \\
X \\
X \\
X \\
X \\
X \\
X \\
X \\
X \\
X \\
X \\
X \\
X \\
X \\
X \\
X \\
X \\
X \\
X \\
X \\
\end{array}$ & & . & . \\
\hline
\end{tabular}

